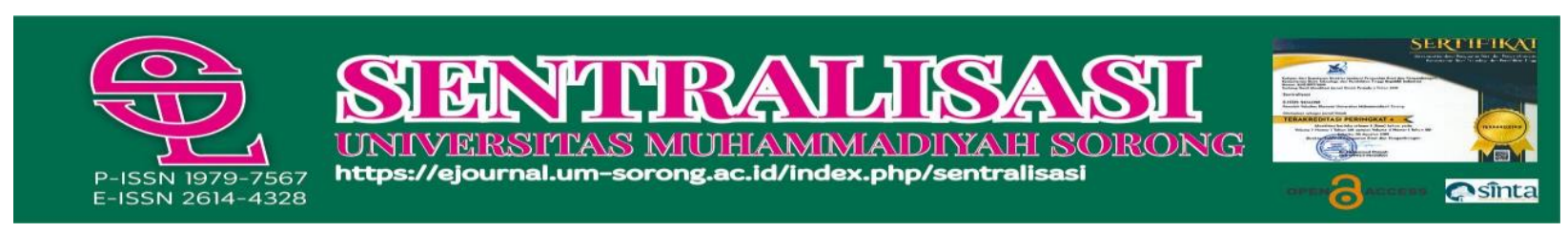

\title{
Saving Behavior in Generation Z
}

\section{Yulianita Rahayu}

Fakultas Ekonomi, Universitas Islam Nusantara, Indonesia

E-mail: yulianitarahayu@ rocketmail.com

Revised: 11/06/2020 Published: 30/06/2020

\begin{abstract}
Abstrak. Penelitian ini memfokuskan pada pengetahuan keuangan dan perilaku menabung pada generasi $\mathrm{Z}$ di Kota Bandung. Tujuan dari penelitian ini adalah untuk mengetahui tingkat pengetahuan keuangan generasi $\mathrm{Z}$ dan menghubungkan pengetahuan keuangan dengan serangkaian informasi terhadap perilaku menabung generasi Z. Penelitian ini menggunakan kuesioner yang dibagikan kepada responden sebanyak 160 orang dan dianalisis melalui validitas, reliabilitas dan regresi linear sederhana. Hasil penelitian in menunjukkan bahwa pengetahuan keuangan memiliki pengaruh tidak signifikan terhadap perilaku menabung, serta memiliki korelasi yang rendah antara pengetahuan keuangan dan perilaku menabung.
\end{abstract}

Kata kunci: Pengetahuan Keuangan, Perilaku Menabung, Generasi Z

Abstract. This study focuses on financial knowledge and saving behavior in Generation Z in Bandung. The aimed of this study is to determine the level of financial knowledge of z generation and relate financial knowledge with a series of information on saving behavior of generation $z$. This study used a questionnaire distributed to respondents of 160 people and analyzed through, validation, reliability, and simple linear regression. The results of this study indicate that financial knowledge has no significant effect on saving behavior, and has a low correlation between financial knowledge and saving behavior.

Keyword: Financial Knowledge, Saving Behavior, Generation Z

\section{Introduction}

Theoretically and empirically prove that economic growth and development is a function of saving. The greater the savings, which are usually indicated by the marginal propencity to saving (MPS) indicator, the greater the country's potential to finance development through investment. But according to the FSA, the level of savings of Indonesian people is still relatively low, at least when measured by the indicator of the ratio of saving to Gross Domestic Product (GDP.The ratio of saving the Indonesian people to GDP has only reached $30.78 \%$ or means it is still far below the figure achieved by the Philippines. The cause is suspected because the Indonesian people are more consumptive. That is why OJK launched a student savings program or SimPel / SimPel iB, with the aim that students and other young people like to save. (www.cnnindonesia.com, 2019)

When the nation's future is determined by the younger generation, its position as an economic driver should receive attention and be prepared from the start. Among them are improving their ability in terms of financial literacy, saving awareness, access to formal financial services and at the same time introducing them to invest. In other words millennial generation must be introduced to the risk aspect, even at a modest level. But from the various sources found, almost all highlight how millennial actually has the potential to save. Their financial behavior will affect the global economy more than the financial behavior of the previous generation. This means that the future of Indonesia is very dependent on the extent of millennial generation financial literacy. 


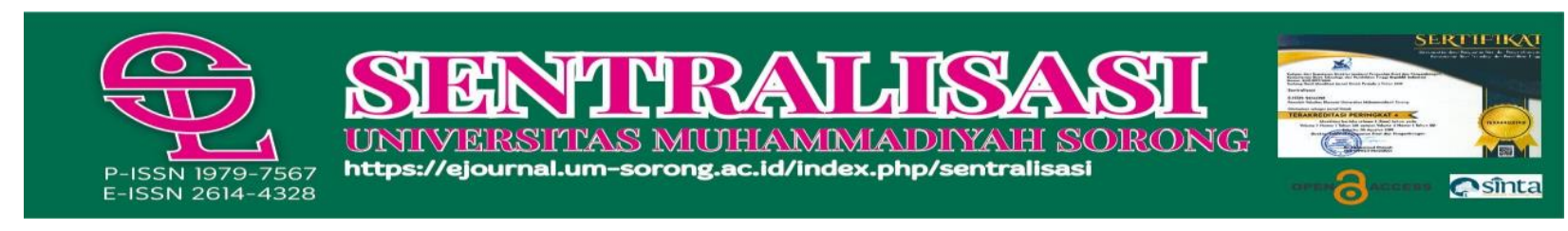

The large portion of today's millennial population is both a challenge and an opportunity for Indonesia. Therefore understanding millennial behavior and then encouraging them to become the driving wheel of the Indonesian economy becomes important and urgent.

The population portion of a country that is categorized as the current generation is often known as millennial generation, and then this generation is grouped into generations $\mathrm{X}, \mathrm{Y}$, and $\mathrm{Z}$. In terms of age, this population group ranges from 20 to 35 years. According to Bappenas data, from the total population of Indonesia in 2018, amounting to 265 million people, approximately 63 million people are included in the group of milleneal generation.

Every month, millennial leaves little of their income to be saved in the form of savings. Based on the results of research released by IDN Times concluded this generation only set aside $10.7 \%$ of their regular income to save. Even though generation $\mathrm{Y}$ and $\mathrm{Z}$ understand the importance of saving, only a small amount of their income is set aside as savings. The results of the research also revealed that savings are the financial products most remembered by the younger generation now (Nugroho, Ekoputri and Halim, 2017). Another survey found that more than $75 \%$ of the younger generation wanted to have the same clothing, vehicles and technological equipment as their environment. Socio-economic life and life style contribute greatly in showing their daily existence. For them, saving is done not to buy assets, but the motivation is to satisfy life style, such as hanging out, drinking coffee, shopping, and luxury holidays.

The young generation must have sufficient financial knowledge to make the best financial choices regarding savings, investment and daily expenses. Those without financial knowledge will eventually lead to poor financial management, which will consequently affect academic performance, mental health conditions and physical well-being.

The results of the OJK survey revealed that the new financial literacy rate touched 38.03 percent, or means that only about 38 out of 100 people have sufficient understanding, skills and trust in financial services (well-literate). This information indicates that the Indonesian people do not yet have an adequate understanding of how to use money and other assets for productive activities. The well-literate young generation is expected to have an impact in driving the country's economy(Lubis, 2020).

Because of the importance of financial literacy in an economy, government efforts to facilitate millennial generation gain financial understanding in their schools and workplaces prove to be very beneficial. Several studies have revealed that financial literacy programs directed at specific behaviors and populations are smart financial decisions (Miller et al., 2014).

Studies on saving behavior have been carried out, especially often correlated with financial knowledge(Utami \& Siren, 2016). However, relatively few have tried to test the predictors of savings among the younger generation, especially generation Z. Previous research on predictors of adolescent saving behavior is still limited to demographic, individual and family factors.

The ongoing discussion is about how adolescent consumption habits are and highlights the importance of understanding their saving behavior. Some researchers find that the younger 


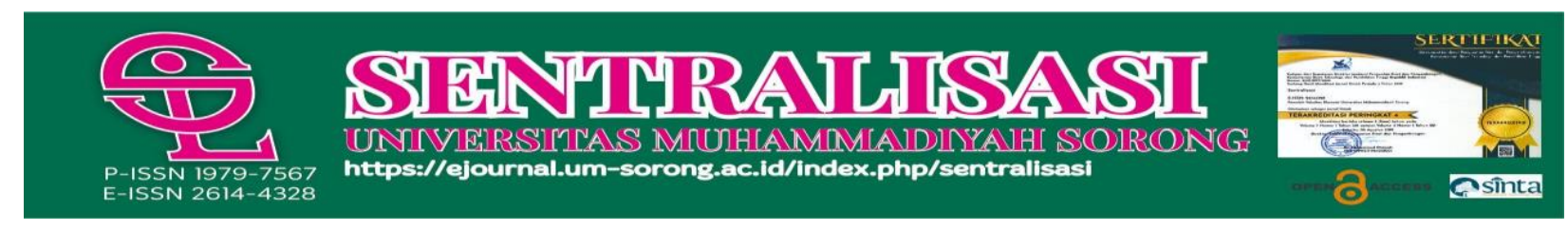

generation tends to spend their income immediately on consumer goods and neglect personal financial management for the long term. While others report that young people save most of their money (Erskine et al., 2006).

Some studies also report on financial knowledge in subgroups or among the entire Indonesian population. However, only a few of his findings are aimed at saving behavior in millennials, especially generation $\mathrm{Z}$. Therefore, this study was conducted in a different context, namely financial knowledge and saving motives in generation $\mathrm{Z}$, where financial knowledge as an independent variable and saving behavior as the dependent variable .

The purpose of this study is to determine the level of financial knowledge of generation $\mathrm{Z}$, map out the determinants that motivate generation $\mathrm{Z}$ to save, and most importantly to connect financial knowledge with a series of information on saving behavior of generation $\mathrm{Z}$.

The findings of this study are expected to be an alternative stimulus and reference for developing programs in an effort to increase saving activities in Generation Z. The expected result is the creation of an increase in saving behavior, financial decision making and financial risks in the future, which in turn will affect the quality of life of young people. which is better and more sustainable for the younger generation. In this regard, getting financial knowledge is not only obtained from formal institutions, such as schools or universities, but also from workshops, seminars and other informal activities.

\section{Research Methods}

This research is exploratory in nature, which is to find out the patterns and motivations of saving activities in generation $\mathrm{Z}$ in Bandung. Descriptive and quantitative analysis will be applied to respondent data to explore patterns of saving behavior and motivation in generation Z. Socioeconomic-demographic differences (profiles) will also be taken into account to identify differences in saving behavior caused by aspects of age, gender, faculties / departments, GPA (Grade Point Average), residence, amount of allowance / allowance per month, have a job or not (full time / part time), income level (for those who are already working), have savings or not, type of savings, saving purpose from respondents. To identify saving behavior patterns, analyze saving motivation, researchers used primary data collected by questionnaire instruments.

Data for this study were collected from the population of generation $\mathrm{Z}$ in the city of Bandung, which ranged in age from 16-25 years, the number reached 475,011 (BPS, 2018)2018. Then by using the Slovin formula and calculating a margin of error of $10 \%$, a minimum sample of 99.98 people is obtained. But the researchers decided to take more samples of 160 people with the expectation of the average nature of the distribution of samples close to normal. Because there is no sampling frame available, sample members are chosen by accident (accidental sampling). Data were collected using a questionnaire instrument consisting of three parts. The first part discusses the personal characteristics of the respondent. Questions were focused on age, gender, faculty / department, GPA, place of residence, amount of allowance / allowance, whether or not working, 


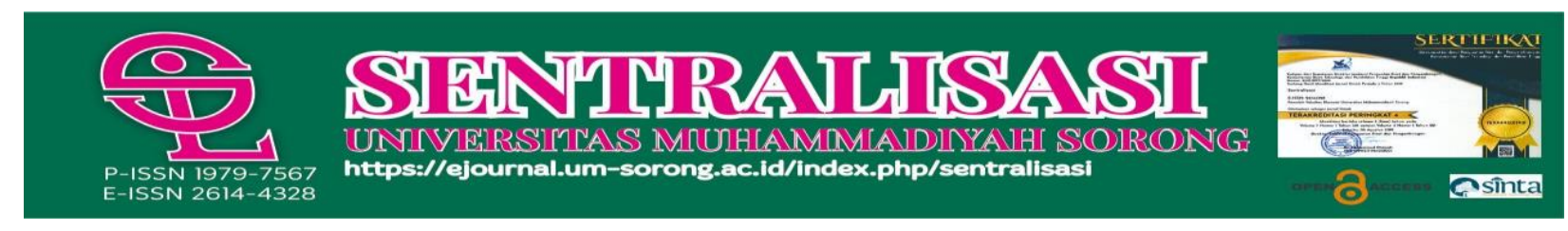

income level (for those who are already working), ownership of savings, types of savings, and saving goals. The second part, including questions about financial knowledge in relation to money management, such as managing budgets and expenses, managing daily financial funds and general personal finance knowledge. Where financial knowledge is one of the variables that influence saving behavior, it is also called an independent variable. The last section asks questions about information about saving behavior, such as savings actions, savings decisions and future needs. Regarding needs, respondents were asked to give their opinions on a five-point Likert scale (1 not at all important to 5 - very important). Where financial knowledge is one of the variables that influence saving behavior, it is also called an independent variable. The last section asks questions about information about saving behavior, such as savings actions, savings decisions and future needs. Regarding needs, respondents were asked to give their opinions on a five-point Likert scale (1 - not at all important to 5 - very important). Where financial knowledge is one of the variables that influence saving behavior, it is also called an independent variable. The last section asks questions about information about saving behavior, such as savings actions, savings decisions and future needs. Regarding needs, respondents were asked to give their opinions on a five-point Likert scale (1 - not at all important to 5 - very important).

To quantitatively estimate the effect of the independent variable on the dependent variable, it is analyzed using the ordinary least square method. Previously, the validity and reliability of the instruments were tested to check the quality of data obtained.

\section{Results and Discussion}

The results of the study were primary data collection through the distribution of questionnaires online. First the researcher tries to explain the results of filling out the questionnaire with descriptive analysis, and then explained with quantitative analysis.

\section{Descriptive Analysis}

Table 1. Profile of Respondents

\begin{tabular}{|c|c|c|c|}
\hline Information & Frequency & Percentage & Total \\
\hline Gender: & & & 160 \\
\hline$\overline{\text { Girl }}$ & 115 & $71.9 \%$ & \\
\hline Male & 45 & $28.1 \%$ & \\
\hline Age: & & & 160 \\
\hline$\leq 18$ years & 13 & $8.1 \%$ & \\
\hline $19-20$ years & 101 & $63.1 \%$ & \\
\hline $21-22$ years & 42 & $26.3 \%$ & \\
\hline$\geq 23$ years & 4 & $2.5 \%$ & \\
\hline Faculty / Department: & & & 160 \\
\hline Economics and Business & 74 & $46.3 \%$ & \\
\hline Non-Economy and Business & 86 & $53.8 \%$ & \\
\hline GPA: & & & 160 \\
\hline$\leq 2.75$ & 19 & $11.9 \%$ & \\
\hline $2.75-3.00$ & 39 & $24.4 \%$ & \\
\hline
\end{tabular}

Yulianita Rahayu 
$3.00-3.25$

$3.25-3.50$

$\geq 3.50$

Residence :

Live with parents

Live Alone / Boarding

Amount of allowance per month: $<$ Rp. 750,000

Rp. 750,000 - Rp. 1,000,000

Rp. 1,000,000 - Rp. 1,500,000

Rp. 1,500,000 - Rp. 2,000,000

$>$ Rp. 2,000,000

Have a Job (Full Time / Part Time):

Yes

Not

Already Have Savings:

Yes

Not

Source: Primary data processed, 2020

Based on Table 1, that the majority of respondents aged 19-20 years (63.1\%) and female sex (71.9\%). The faculties / departments taken by the respondents are mostly non-economic and business $(53.8 \%)$. The cumulative achievement index (GPA) of the majority of respondents is above $3.50(25 \%)$. The majority of respondents' homes were with parents $(67.5 \%)$. Most respondents have Amount of allowance / allowance per month under Rp. 750,000. A small portion of respondents $(38 \%)$ of respondents already worked, both working full time and part time. And only a small proportion of respondents who do not have savings, either own savings or have savings in the bank, which is equal to (13.8\%). Although most respondents already have savings, but they still use the piggy bank or save themselves to save and set aside the money.

If seen from the results of the calculation of the continuum line, most respondents have quite good financial knowledge, which is $79.5 \%$. One reason is because, generation $\mathrm{z}$ was born where access to information, especially from the internet has become a necessity, so that it makes it easier for them to find information and learn many things, especially about financial knowledge. So that it affects the values, their views on money.

Even though the percentage of respondents aged 19-20 years and female gender is greater, there is no difference in financial knowledge. Likewise the faculties / departments, Cumulative Achievement Index (GPA), residence, the amount of allowance / allowance per month and have a job or not, do not have a difference in terms of financial knowledge. This is presented in table 2 . From asymp. sig ( 2 sided) uses Pearson Chi Square for the correlation of all categories of financial knowledge having values above 0.05 .

Yulianita Rahayu 
Table 2. Chi-Square Test of Financial Knowledge

\begin{tabular}{lcc}
\hline $\begin{array}{c}\text { Test the Association of Financial } \\
\text { Knowledge with: }\end{array}$ & $\begin{array}{c}\text { Asymp. Sig. (2- } \\
\text { sided)using Pearson } \\
\text { Chi-Square }\end{array}$ & $\begin{array}{c}\text { Information } \\
\text { Age }\end{array}$ \\
Gender & 0.884 & There is no relationship \\
Faculty / Department & 0.173 & There is no relationship \\
GPA & 0.286 & There is no relationship \\
Residence & 0.629 & There is no relationship \\
Amount of allowance / month & 0.748 & There is no relationship \\
Have a Job & 0.951 & There is no relationship \\
\hline
\end{tabular}

Source: Primary data processed, 2020

Based on the profile of respondents who tested the saving behavior variable using the Chi-

Square test (Table 3), it was seen that only the age variable had an association with saving behavior, meaning that age had a relationship with saving behavior in generation $Z$. This was because most of the generation $\mathrm{Z}$ not yet financially independent in the sense that they have not worked permanently so they do not have a fixed income every month and their motivation for saving is only for short-term benefits. While the gender variable, faculty / department, Cumulative Achievement Index (GPA), residence, amount of allowance / allowance per month, have a job or not (either Full Time or Part Time) and have a job or not, do not have an association. The meaning of not having association is gender differences, faculty / department, Cumulative Achievement Index (GPA), place of residence, the amount of allowance / allowance per month and work or not, not associated with saving behavior of generation $\mathrm{Z}$. This is indicated by the asymp value. sig. (2sided) using Pearson Chi-Square whose value is greater than 0.05 as shown in the following table:

Table 3. Chi-Squar Teste Savings Behavior

\begin{tabular}{lcl}
\hline $\begin{array}{c}\text { Association Test between Savings } \\
\text { Behavior with: }\end{array}$ & $\begin{array}{c}\text { Asymp. Sig. (2- } \\
\text { sided) using Pearson } \\
\text { Chi-Square }\end{array}$ & \multicolumn{1}{c}{ Information } \\
\hline Age & 0.035 & There is a relationship \\
Gender & 0.068 & There is no relationship \\
Faculty / Department & 0.279 & There is no relationship \\
GPA & 0.073 & There is no relationship \\
Residence & 0.691 & There is no relationship \\
Amount of allowance / allowance & 0.194 & There is no relationship \\
per month & 0.678 & There is no relationship \\
Have a Job & &
\end{tabular}

Source: Primary data processed, 2020

\section{Validity and Reliability Test}

To see whether the empirical indicators of the variables used in this study are valid and reliable, a validity and reliability test is performed. From the results of the validity analysis test, obtained value of the item score with a total score. This value is then compared with the $r$ table value. $R$ table is sought at $5 \%$ significance advertisment with a 2 -tailed test and $n=160$ then the $r$ 
table is 0.155 (Table 4), which means that the statement items used in this study are suitable for use as measurement instruments. Furthermore, the reliability test using the Cronbach's Alpha method, obtained an Alpha value of 0.849, while the critical r value (2-sided test) at a significance of $5 \%$ with $n=160(d f=n-2=158)$, in the amount of 0.155 . Then it can be concluded that the points of the research instrument are reliable, which means that this instrument can provide the right results and can be justified.

Table 4. Test the validity of the Statement Items

\begin{tabular}{|c|c|c|c|c|c|c|c|}
\hline $\begin{array}{c}\text { No. } \\
\text { Stateme } \\
\text { nt Items }\end{array}$ & $\begin{array}{c}\mathbf{r} \\
\text { Calcula } \\
\text { te }\end{array}$ & $\begin{array}{c}\mathbf{r} \\
\text { Tabl } \\
\mathbf{e} \\
\end{array}$ & $\begin{array}{c}\text { Interpretati } \\
\text { on }\end{array}$ & $\begin{array}{c}\text { No. } \\
\text { Stateme } \\
\text { nt Items }\end{array}$ & $\begin{array}{c}\mathbf{r} \\
\text { Calcula } \\
\text { te }\end{array}$ & $\begin{array}{c}\mathbf{r} \\
\text { Tabl } \\
\mathbf{e} \\
\end{array}$ & $\begin{array}{c}\text { Interpretati } \\
\text { on }\end{array}$ \\
\hline \multirow{3}{*}{ PK 1} & & 0.15 & \multirow{3}{*}{ Valid } & \multirow{3}{*}{ PM 1} & & 0.15 & \multirow{3}{*}{ Valid } \\
\hline & 0.331 & 5 & & & 0.381 & 5 & \\
\hline & & 0.15 & & & & 0.15 & \\
\hline \multirow[t]{2}{*}{ PK 2} & 0.560 & 5 & \multirow[t]{2}{*}{ Valid } & \multirow[t]{2}{*}{ PM 2} & 0.513 & 5 & \multirow[t]{2}{*}{ Valid } \\
\hline & & 0.15 & & & & 0.15 & \\
\hline \multirow{2}{*}{ PK 3} & 0.406 & 5 & \multirow{2}{*}{ Valid } & \multirow[t]{2}{*}{ PM 3} & 0.549 & 5 & \multirow[t]{2}{*}{ Valid } \\
\hline & & 0.15 & & & & 0.15 & \\
\hline \multirow[t]{2}{*}{ PK 4} & 0.569 & 5 & \multirow[t]{2}{*}{ Valid } & \multirow[t]{2}{*}{ PM 4} & 0.647 & 5 & \multirow[t]{2}{*}{ Valid } \\
\hline & & 0.15 & & & & 0.15 & \\
\hline \multirow[t]{2}{*}{ PK 5} & 0.550 & 5 & \multirow[t]{2}{*}{ Valid } & \multirow[t]{2}{*}{ PM 5} & 0.535 & 5 & \multirow[t]{2}{*}{ Valid } \\
\hline & & 0.15 & & & & 0.15 & \\
\hline \multirow[t]{2}{*}{ PK 6} & 0.596 & 5 & \multirow[t]{2}{*}{ Valid } & \multirow[t]{2}{*}{ PM 6} & 0.459 & 5 & \multirow[t]{2}{*}{ Valid } \\
\hline & & 0.15 & & & & 0.15 & \\
\hline \multirow[t]{2}{*}{ PK 7} & 0.680 & 5 & \multirow[t]{2}{*}{ Valid } & \multirow[t]{2}{*}{ PM 7} & 0.426 & 5 & \multirow[t]{2}{*}{ Valid } \\
\hline & & 0.15 & & & & 0.15 & \\
\hline \multirow[t]{2}{*}{ PK 8} & 0.587 & 5 & \multirow[t]{2}{*}{ Valid } & \multirow[t]{2}{*}{ PM 8} & 0.570 & 5 & \multirow[t]{2}{*}{ Valid } \\
\hline & & 0.15 & & & & 0.15 & \\
\hline \multirow[t]{2}{*}{ PK 9} & 0.435 & 5 & \multirow[t]{2}{*}{ Valid } & PM 9 & 0.526 & 5 & Valid \\
\hline & & 0.15 & & & & & \\
\hline PK 10 & 0.448 & 5 & Valid & & & & \\
\hline & & 0.15 & & & & & \\
\hline PK 11 & 0.440 & 5 & Valid & & & & \\
\hline
\end{tabular}

\section{Quantitative Analysis}

The quantitative approach here aims to determine the effect of financial knowledge on saving behavior. Based on regression testing the following results were obtained:

Table 5. Correlation Results Between Variables

\begin{tabular}{llllr}
\hline Model & $R$ & R Square & Adjusted R Square & Std. Error of the Estimate \\
\hline 1 & $.380 \mathrm{a}$ & .144 & .22 & 42,145 \\
\hline
\end{tabular}

a. Predictors: (Constant), X1

Source: Primary data processed, 2020

Table 5 above shows the $\mathrm{R}$ value (correlation value) is 0.380 . This value can be interpreted that the relationship between the two variables of financial knowledge and saving behavior is in 
the weak category. And obtained R square of 0.144 which shows the financial knowledge variable contributed $14.4 \%$ to changes in the saving behavior variable.(Wahana, 2014)

Table 6. Significance Results and Regression Models

\begin{tabular}{|c|c|c|c|c|c|c|}
\hline \multirow[t]{2}{*}{ Model } & & \multicolumn{2}{|c|}{ Unstandardized Coefficients } & \multirow{2}{*}{$\begin{array}{c}\text { Standardized } \\
\text { Coefficients } \\
\text { Beta }\end{array}$} & \multirow[t]{2}{*}{$\mathrm{t}$} & \multirow[t]{2}{*}{ Sig. } \\
\hline & & B & Std. Error & & & \\
\hline \multirow{2}{*}{1} & (Constant) & 519,573 & 136,243 & & 3,814 & .007 \\
\hline & $\mathrm{X} 1$ & .233 & .214 & .380 & 1,086 & .313 \\
\hline
\end{tabular}

a. Dependent Variable: $Y 1$

Source: Primary data processed, 2020

Based on statistical results (Table 6), the calculated $\mathrm{F}$ value is obtained with a significant level of $0.313>0.05$ which means that the relationship of financial knowledge has no significant effect on saving behavior. With the equation model:

$$
\mathrm{Y}=519,573+0.233 \mathrm{X}
$$

Which means: 1) A constant of 519,573 states that if there is no value of financial knowledge, then the value of saving behavior is 519,573. 2) The regression coefficient $X$ of 0.233 states that for each addition of 1 value of financial knowledge, the value of saving behavior increases by 0.233 .

\section{Conclusions}

Based on the results of the study it can be concluded, that with a quantitative approach shows the relationship of financial knowledge and saving behavior is very low. This is also reinforced by the value of the contribution of the financial knowledge variable to the saving behavior variable, which is $14.4 \%$. This means that there are still many other factors that will influence saving behavior in Generation Z. While based on a descriptive approach illustrates that this generation already has sufficient financial knowledge, especially regarding budgeting for personal needs and expenses and some financial products. Even for generation $\mathrm{Z}$ who already has a job, it is quite difficult to set aside his income in the form of savings. This is because their average income is between Rp. 1,000,000 - Rp. 2,000,000. most of their income is used for daily needs. The main factors that encourage generation $\mathrm{Z}$ to save are to finance their own education, this is to help parents, to buy goods and go on vacation or recreation. This can be understood because this generation tends to be consumptive to support lifestyles. Basically this generation can save money, it's just thatsavingsthis is not for the future, but to fulfill the wishes of the present. So there are still many of them who have not used the bank as a place to save, most of them still save using conventional piggy bank or savings, which are considered easier and more practical if there are unexpected or sudden expenses.

\section{Bibliography}

Aliah, Siti; Krisnawati, A. (2019). Analisis Perbedaan Tingkat Literasi Keuangan Dan Perilaku 
https://ejournal.um-sorongacid/index.php/sentralisas

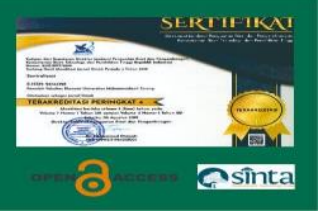

Keuangan Mahasiswa Di Universitas Telkom. Jurnal Mitra Manajemen, 3, 109-120. http://ejurnalmitramanajemen.com/index.php/jmm/article/view/125/69

Chen, H., \& Volpe, R. P. (1998). An Analysis of Personal Financial Literacy Among College Students. 7(2), 107-128.

Desi Marwati, R. (2018). Faktor-Faktor Yang Mempengaruhi Perilaku Menabung Mahasiswa Fakultas Ekonomi Universitas Negeri Yogyakarta.

Dewi, D. A. N. N. (2018). Modul Uji Validitas dan Reliabilitas. Researchgate, October, 1-15. www.researchgate.net/

Erskine, M., Kier, C., Leung, A., \& Sproule, R. (2006). Peer crowds, work experience, and financial saving behaviour of young Canadians. Journal of Economic Psychology, 27(2), 262-284. https://doi.org/10.1016/j.joep.2005.05.005

Febria Larasati, N. (2019). Analisis Perilaku Generasi Milenial Terhadap Niat Menjadi Nasabah Bank syariah. http://repository.uinjkt.ac.id/dspace/bitstream/123456789/46867/1/Niken Febria Larasati-FEB.pdf

Generasi Milenial Melek Finansial, Ini Dampaknya bagi Negeri | Indozone.id. (n.d.). Retrieved April 6, 2020, from https://www.indozone.id/life/5jsbg3/generasi-milenial-melek-finansialini-dampaknya-bagi-negeri/read-all

Generation Gap: Pengelolaan Keuangan Milenial dan Gen Z. (n.d.). Retrieved April 6, 2020, from http://avrist.com/lifeguide/2020/01/31/pengelolaan-keuangan-milenial-dan-gen-zgeneration-gap/

Hidayat, A. (n.d.). Regresi Linear Sederhana dengan SPSS - Uji Statistik. Retrieved April 18, 2020, from https://www.statistikian.com/2012/08/regresi-linear-sederhana-dengan-spss.html

Humaira, I. (2017). Pengaruh Pengetahuan Keuangan, Sikap Keuangan Dan Kepribadian terhadap Perilaku Manajemen Keuangan Pada Pelaku UMKM Sentra Kerajinan Batik Kabupaten Bantul.

Lusardi, A. (2008). Financial Literacy: an Essential Tool for Informed Consumer Choice? http://www.nber.org/papers/w14084

Mendari, Anastasia Sri ; Kewal, S. S. (2013). Tingkat Literasi Keuangan Di Kalangan Mahasiswa STIE Musi. Jurnal Economia, 9(2), 130-140. https://doi.org/10.21831/economia.v9i2.1804

Ming Thung, C., Ying Kai, C., Sheng Nie, F., Wan Chiun, L., \& Chang Tsen, T. (2012). Determinants of saving behaviour among the university students in Malaysia. Universiti Tunku Abdul Rahman, May, 109. http://eprints.utar.edu.my/607/1/AC-2011-0907445.pdf

Mohammed Esmail Alekam, J., Salniza Bt Md. Salleh, M., \& Sanuri bin Mohd. Mokhtar, S. (2018). The Effect of Family, Peer, Behavior, Saving and Spending Behavior on Financial Literacy among Young Generations. International Journal of Organizational Leadership, 7(3), 309323. https://doi.org/10.33844/ijol.2018.60258

OJK Klaim Rasio Menabung RI Kalah dari Filipina. (n.d.). Retrieved April 6, 2020, from https://www.cnnindonesia.com/ekonomi/20190528131453-78-399056/ojk-klaim-rasiomenabung-ri-kalah-dari-filipina

Perilaku Finansial Generasi Milenial. (n.d.). Retrieved April 10, 2020, from https://news.detik.com/kolom/d-4915295/perilaku-finansial-generasi-milenial 
Pradiningtyas, T. E., Lukiastuti, F., Bank, S., Jateng, B. P. D., Abstrak, S., Semarang, K., \& Kunci, K. (2019). Pengaruh Pengetahuan Keuangan Dan Sikap Keuangan Terhadap Locus Of Control Dan Perilaku Pengelolaan Keuangan. 6(1), 96-112.

Pritazahara, R., Sriwidodo, U., Program, ), Manajemen, S., Ekonomi, F., Slamet, U., \& Surakarta, R. (2015). Pengaruh Pengetahuan Keuangan dan Pengalaman Keuangan Terhadap Perilaku Perencanaan Investasi Dengan Self Control Sebagai Variabel Moderating. Jurnal Ekonomi Dan Kewirausahaan, 15(1), 28-37.

Putra, Y. S. (2016). Theoritical Review : Teori Perbedaan Generasi. 9.

Rudiwantoro, A. (2018). Langkah Penting Generasi Millennial Menuju Kebebasan Finansial Melalui Investasi. $\quad$ Moneter, $\quad V(1), \quad 46$. http://ejournal.bsi.ac.id/ejurnal/index.php/moneter/article/view/2502/2168

Sina, Peter Garlans; Noya, A. (2012). Pengaruh Kecerdasan Spiritual Terhadap Pengelolaan Keuangan Pribadi. Pengaruh Kecerdasaan Spirtual Terhadap Pengelolaan Keuanagan Pribadi, 11(2), 171-188.

Sriprasert, P., Chainin, O., \& Rahman, H. A. (2014). Understanding Behavior and Needs of Halal Tourism in Andaman Gulf of Thailand: A Case of Asian Muslim. Journal of Advanced Management Science, 216-219. https://doi.org/10.12720/joams.2.3.216-219

Suhendra, Y. F., \& Arifin, A. Z. (2019). Faktor Yang Memprediksi Perilaku Menabung Pekerja Di Jakarta. Jurnal Manajerial Dan Kewirausahaan, I, No. 3(3), 600-608.

Suroso, P.C; Pattiwael, Judith. F; Izharivan, Yodi; Kusuma, C. (2015). Faktor-Faktor Yang Mempengaruhi Perilaku Menabung Masyarakat Berpenghasilan Rendah. Iii.

Survei IMS 2019: Millennieal Tidak Suka Menabung. (n.d.). Retrieved April 6, 2020, from https://www.idntimes.com/business/economy/ananta-fitri/survei-ims-2019-millenniealtidak-suka-menabung/full

Ulasan Keuangan untuk Generasi Kelahiran 80an dan 90an (Gen Y \& Z). (n.d.). Retrieved April 6, 2020, from https://www.aturduit.com/articles/karakter-keuangan-generasi-y-dan-z/

Utami, D. S., \& Sirine, H. (2016). Faktor-Faktor Yang Memengaruhi Perilaku Menabung Di Kalangan Mahasiswa. Jurnal Ekonomi Dan Bisnis, 19(1), 27-52.

Wahana, A. (2014). Analisis Faktor-Faktor Yang Mempengaruhi Perilaku Mahasiswa Dalam Menabung ( Studi Kasus Mahasiswa S1 Feb Undip Tembalang ). In skripsi, Universitas Diponegoro.

Warneryd, K., \& Erik; Elgar, E. (2001). The Psychology of Saving: A Study on Economic Psychology. Journal of Economic Psychology, 22(2), 295-299. https://doi.org/10.1016/s0167-4870(00)00038-6

Yulianti, N., \& Silvy, M. (2013). Sikap Pengelola Keuangan Dan Perilaku Perencanaan Investasi Keluarga Di Surabaya. Journal of Business and Banking, 3(1), 57-68. 